\title{
Bank Failure in Nigeria: Evidence of Prudential Regulator Laxity
}

\author{
Iwedi Marshal \\ Department of Banking \& Finance Rivers State University, Port Harcourt, Nigeria \\ Email: iwedimarshal@yahoo.com
}

\begin{abstract}
The series of bank failure in Nigeria have raised doubt in the minds of banking and non banking public about the efficacy of the prudential regulator and its frameworks. This is due to the fact that a substantial number of these groups are questioning the roles of the prudential regulator saddles with the responsibility of regulating and supervising the activities of banks together with the laws governing the operation and conduct of banking business in Nigeria. The incessant failure witness in the banking sector over these years is captured by the number of failed banks, spate of non performing credits, the debt and extent of required capitalization, loss of depositors funds and the general impact on the economy all of which underscores the importance of the sector. A study of this nature examined bank failure in Nigeria and those responsible for such series of failures. It was discovered that the Nigeria banking sector regulatory authorities are responsible and are to be blamed for these incessant rates of failures in the banking sector of the Nigeria economy. We conclude that the failure experience in the sector in recent times is attributed to regulatory laxity on the part of the prudential regulators occasioned by their inability and delay to carry out some of its routine, off site, and on site functions as stipulated in the mandate establishing CBN and failures to ensure compliance to the prudential guidelines.
\end{abstract}

Keywords: Bank failure, prudential regulator, regulatory framework, Nigeria economy.

\section{Introduction}

The banking system in Nigeria has come under search light in recent times not only because of its intermediation roles but also as a result of the problem rocking the sector in terms of failures and eventual distress among banks. Although, the banking system serves as the nerve center of any modern economy, it facilitates economic growth and provides a mechanism for the transmission of government monetary policy (Golin, 2001). This is because the banks take on public policy function, their regulation and supervision by the government is justified. Moreover, the risks and vulnerabilities that banks confront as a consequence of their very structure and function provide another reason for the authorities to monitor bank operation closely.

The series of failure experienced in the banking sector over the years can be captured by the number of failed banks, spate of nonperforming loans, the debt and extent of required capitalization, loss of depositors funds and the general impact on the economy all of which underscores the importance of the sector. These series of failures, distress or collapse witnessed over the period could be attributed to prudential regulatory laxity on the part of the sector regulators which is acceptably blamed to the failure of the CBN to carry out some of its routine functions, inadequate regulatory frameworks or regime, failure to set standards of regulation and ensure compliance by the various commercial banks in the country. These failures grow unabated even when regulations like CBN act of 1958 as amended, BOFIA of 1991 as amended, Prudential Guideline on Asset Classification and Provision for Loan Losses (SAS 10) as well as failed Bank (Recovery of Debts) and Other Financial Malpractices Act of 1994 were all in existence. Looking at this, it can be concluded therefore that the series of bank failures in Nigeria are to be blamed on the prudential regulator or that the regulatory frameworks are inadequate to address the incessant bank failures in the sector. These are questions previous studies have not fully answered. It is therefore the crux of the study to provide answers to the questions. 


\section{$2 \quad$ Literature Review}

\subsection{Historical Development of Bank Failures in Nigeria}

Bank failure has been described as the state where a bank is unable to meet its financial obligations such as interbank indebtedness, repayment of depositors' funds, honoring maturing obligation etc. Such a situation is caused by the presence of weak deposit base, poor capital base, poor management, asset mismatch or even weakness in operational conditions (Nzotta, 2004). However, Bank failure in Nigeria will be discussed in phases as follow:

\subsubsection{First Phase of Bank Failure (1930-1968)}

Bank failure in this era could be traced to the free banking era that prevailed before the introduction of banking ordinance of 1952. The free era saw the establishment of African Banking Corporation (ABC) in 1892, now First Bank of Nigeria plc. During this era, there were no forms of regulation in the banking system. Thus, many banks were established at random and some of them failed as quickly as they emerged. Available statistics show that the first bank failure in Nigeria was recorded in 1930 when industrial and commercial bank was limited, the first indigenous bank was closed. There is no gain saying the fact that millions of Nigerians lost their investments and hard time savings in these failed banks, while some lives were lost as a result of the shocks caused by their financial losses. Table 1 below shows the names and years of failed banks in Nigeria.

Table 1. Failed banks in Nigeria (1936-1968)

\begin{tabular}{lll}
\hline NAME & YEAR ESTABLISHED & YEAR CLOSED \\
\hline (1) Nigerian Mercantile Bank Ltd & 1931 & 1936 \\
\hline (2) Nigerian Farmers \& Comm. Bank Ltd & 1947 & 1953 \\
\hline (3) Pan Nigerian Bank Ltd. & 1951 & 1954 \\
\hline (4) Standard Bank of Nig. Ltd & 1951 & 1954 \\
\hline (5) Premier Bank Ltd. & 1951 & 1954 \\
\hline (6) Nigerian Trust Bank Ltd. & 1951 & 1954 \\
\hline (7) Afro-Seas Credit Bank Ltd. & 1951 & 1954 \\
\hline (8) Onward Bank of Nigeria Ltd. & 1951 & 1954 \\
\hline (9) Central Bank of Nigeria Ltd & & 1954 \\
\hline (Not affiliated with present day) & 1951 & 1954 \\
\hline (10) Merchant Bank Ltd. & 1952 & 1954 \\
\hline (11) Metropolitan Bank of Nig. Ltd. & 1952 & 1954 \\
\hline (12) Provincial Bank of Nig. Ltd. & 1952 & 1954 \\
\hline (13) Union Bank of British Africa Ltd & 1952 & 1954 \\
\hline (14) United Commercial Credit Bank Ltd & 1952 & 1954 \\
\hline (15) Mainland Bank Ltd. & 1952 & 1954 \\
\hline (16) Cosmopolitan Credit Bank Ltd. & 1952 & 1954 \\
\hline (17) Group Credit \& Credit Bank Ltd & 1952 & 1954 \\
\hline (18) Industrial Bank Ltd. & 1952 & 1954 \\
\hline (19) West African Bank Ltd. & 1952 & \\
\hline (20) Bank of Lagos & 1959 & \\
\hline
\end{tabular}

Source: CBN Economic \& Financial Review. Vol. 6 No. 1 (1968)

\subsubsection{Second Phase of Bank Failure (1968-2000)}

The period 1968-2000 witnessed another round of bank failure in Nigeria which resulted in a good number of banks having their licenses revoked by the CBN (Ohwofasa \& Mayuku, 2012). During this era, the number of banks classified as failed increased from nine (9) to fifty two (52) while the licenses of 
five (5) banks were revoked in 1994 and 1995 respectively (Adeyemi, 2011). A look at table 2 below shows the names and years of failed banks in Nigeria.

Table 2. Failed banks in Nigeria (1968-2000)

\begin{tabular}{|c|c|c|}
\hline NAME & YEAR ESTABLISHED & YEAR CLOSED \\
\hline (1) Allied Bank of Nig. Plc & 1962 & 1968 \\
\hline (2) Amicable Bank of Nig. Plc & 1991 & 1998 \\
\hline (3) Commercial Bank Nig. Plc & 1988 & 1998 \\
\hline (4) Commerce Bank of Nig. Plc & 1989 & 1998 \\
\hline (5) Co-operative \& Comm. Bank Plc & 1954 & 1998 \\
\hline (6) Credite Bank Nig. Ltd. & 1990 & 1998 \\
\hline (7) Highland Bank Plc & 1988 & 1998 \\
\hline (8) Lobi Bank of Nig. Ltd. & 1983 & 1994 \\
\hline (9) Mercantile Bank of Nig. Plc & 1971 & 1998 \\
\hline (10) North-South Bank of Nig. Plc & 1988 & 1998 \\
\hline (11) Pan African Bank Ltd. & 1971 & 1998 \\
\hline (12) Pinnacle Comm. Bank Ltd. & 1991 & 1998 \\
\hline (13) Premier Com. Bank Ltd. & 1987 & 2000 \\
\hline (14) Progress Bank of Nig. Ltd & 1982 & 1998 \\
\hline (15) Republic Bank Ltd. & 1989 & 1995 \\
\hline (16) United Comm. Bank Ltd. & 1991 & 1994 \\
\hline \multicolumn{3}{|l|}{ Merchant Banks } \\
\hline (1) Abacus Merchant Bank Ltd & 1987 & 1998 \\
\hline (2) Alpha Merchant Bank Ltd. & 1981 & 1994 \\
\hline (3) Century Merchant Bank Ltd. & 1988 & 1998 \\
\hline (4) ABC Merchant Bank Ltd. & 1984 & 1998 \\
\hline (5) Continental Merchant Bank Ltd. & 1975 & 1998 \\
\hline (6) Crown Merchant Bank Ltd. & 1988 & 1998 \\
\hline (7) Great Merchant Bank Ltd & 1990 & 1998 \\
\hline (8) Group Merchant Bank Ltd. & 1990 & 1998 \\
\hline (9) Icon Merchant Bank Ltd & 1975 & 1998 \\
\hline (10) Ivory Merchant Bank Ltd. & 1989 & 2000 \\
\hline (11) Merchant Bank Ltd. & 1987 & 1998 \\
\hline (12) Nigerian Merchant Bank Ltd. & 1973 & 1998 \\
\hline (13) Prime Merchant Bank Ltd. & 1988 & 1998 \\
\hline (14) Royal Merchant Bank Ltd. & 1991 & 2000 \\
\hline (15) Victory Merchant Bank Ltd. & 1990 & 1998 \\
\hline
\end{tabular}

Source: NDIC Annual Report 2002.

\subsubsection{Third Phase of Bank Failure (2000-2009)}

The banking sector reforms in 2004 ended up with fourteen out of the eighty nine banks disappearing from the scene. During this 18 months period reform of CBN, there were a number of merger and acquisitions among banks in Nigeria in order to meet the new capital requirement of \#25 billion. At the end, 89 banks that existed in 2004 reduced to 25 larger, better-capitalized banks. 
Table 3. Failed banks as at December, 2009

\begin{tabular}{ll}
\hline Failed Banks & Date of Closure \\
\hline 1) Allstates Trust Bank Plc & 16-Jan-2006 \\
\hline 2) Afex Bank Limited & 16-Jan-2006 \\
\hline 3) Assurance Bank Nig. Limited & 16-Jan-2006 \\
\hline 4) City Express Bank Plc & 16-Jan-2006 \\
\hline 5) Eagle Bank Limited & 16-Jan-2006 \\
\hline 6) Fortune International Bank Plc & 16-Jan-2006 \\
\hline 7) Gulf Bank Plc & 16-Jan-2006 \\
\hline 8) Hallmark Bank Plc & 16-Jan-2006 \\
\hline 9) Lead Bank Plc & 16-Jan-2006 \\
\hline 10) Liberty Bank Plc & 16-Jan-2006 \\
\hline 11) Metropolitan Bank Limited & 16-Jan-2006 \\
\hline 12) Trade Bank Plc & 16-Jan-2006 \\
\hline 13) Triumph Bank Limited & 16-Jan-2006 \\
\hline
\end{tabular}

Source: NDIC Annual Report 2009

\subsubsection{Fourth Phase of Bank Failure}

2009 saw another round of bank failure in Nigeria. This failure came on the heels of joint CBN/NDIC special investigation into the books of the 25 banks operating in the country as at that date. The findings of the investigation revealed that the banks were technically insolvent on account of capital, poor credit risk management, liquidity and lack of corporate governance (Sanusi, 2009). Table 4 below shows that the Bridge Banks were created by CBN to assume the assets and liabilities of three of the six failed banks while the remaining three were taken over by three other existing banks. All the failed banks had exceeded their credit ceilings through unauthorized lending's and other micro-financial credit risk abuses that were estimated to be in excess of N700 billion (Ugoani, 2015). The Bridge Banks will serve as undertakers specifically set up to attempt to manage the assets and liabilities of the failed banks with little or no compensation to shareholders of the failed banks.

Table 4. Details of failed banks in Nigeria in 2011

\begin{tabular}{llll}
\hline S/N & Name of Failed Banks & Name of bridge Bank & Failed Bank taken over by \\
\hline 1 & Afribank & Mainstreet Bank & \\
\hline 2 & Bank PHB & Keystone Bank & \\
\hline 3 & Spring Bank & Enterprise Bank & \\
\hline 4 & Fin Bank & & First City Monument Bank \\
\hline 5 & Intercontinental Bank & Access Bank \\
\hline 6 & Oceanic Bank & Eco Bank \\
\hline
\end{tabular}

Source: NDIC Report, 2011

\subsection{Banks Regulatory Framework and Institutions in Nigeria}

Banking activities in Nigeria are governed by rules and regulations which are reviewed from time to time to reflect the changing economic environment. Among some of the recent rules and statutes which govern the operation of the banks are the Central Bank of Nigeria Decree No. 24 of 1999 as amended, Bank and Other Financial Institutions Decree No. 25 of 1991 as amended, the Dishonored Cheque (offenses) Decree of 1977, the Failed Bank (Recovery of Debt) Decree No. 18 of 1994 as amended, and the money Laundering decree no 3 of 1995. Other relevant laws which affect the operation of the financial system include the Foreign Exchange (Monitoring and Miscellaneous Provisions) Decree No 17 of 1995, Nigerian Investment and Promotion Commission Decree No 16 of 1995, and the Companies and 
Allied Matters Decree No 1of 1990, which provides the legal framework for Unit Trust Operation in the country (Nwatt, 2016). The Investment and Securities Act (ISA) 2007 gave SEC power to regulate all quoted companies, including Banks operating in Nigeria. The Insurance Act 2003 vested the responsibility to regulate and supervise insurance businesses on NAICOM. Section 4(1) of the Act states that "subject to the provisions of the Act, no insurer shall commence business in Nigeria unless the insurer is registered by NAICOM". Also, NAICOM Act 2007 empowered it to license and supervise the operations of all classes of insurance business in Nigeria. NDIC Act 2006 vested the Nigeria Deposit Insurance Corporation with the supervisory powers and responsibilities over deposit taking by Financial Institutions (FIs) in addition to the deposit insurance and orderly liquidation of failed banks. The CBN Act 1994 and 2007 as amended led to the creation of the FSRCC which coordinates and harmonizes the activities of the various regulators and supervisors in the financial system with a view to minimizing regulatory arbitrage. The Committee is chaired by the Governor of the CBN. However, the regulatory/supervisory authorities of the financial institutions include:

\subsubsection{Central Bank of Nigeria (CBN)}

Section 2(d) of the CBN Act 2007 vested on the CBN the statutory responsibility of promoting a sound financial system in Nigeria. Also, Section 33(1) (a) (b) empowers the Bank to require certain information from and issues guidelines to Financial Institutions on matters relating to their activities and the economy, while Section 42(1) (b) mandates the Bank to ensure high standards of conduct and management throughout the banking system. Section 30 of the BOFIA requires the Governor of the CBN to appoint an officer of the Bank known as Director of Banking Supervision or by such other title as the Governor may specify who shall have the power to carry out supervisory oversight on banks and other financial institutions. Sections 31-34 further empower the Bank to conduct both routine and special examination of banks and to either impose sanctions for contraventions or take remedial actions on banks in grave financial conditions.

\subsubsection{Nigeria Deposit Insurance Corporation (NDIC)}

NDIC Act 2006 vested the Nigeria Deposit Insurance Corporation with the supervisory powers and responsibilities over deposit taking by Financial Institutions (FIs) in addition to the deposit insurance and orderly liquidation of failed banks. However, the Nigerian Deposit Insurance Corporation (NDIC) exercises shared responsibility with the Central Bank of Nigeria for the supervision of insured banks. Active co-operation exists between these two agencies on the focus and modality for regulating and supervising insured banks. This is exemplified in the coordinated formulation of supervisory strategies and surveillance on the activities of the insured banks, elimination of supervisory overlap, establishment of a credible data management and information sharing system.

Other regulatory/supervisory agencies in the Nigerian financial system include:

\subsubsection{Securities and Exchange Commission (SEC)}

The SEC derives its power to regulate all quoted companies, including FIs, and other capital market operators from the Investment and Securities Act (ISA) 2007.

\subsubsection{National Insurance Commission (NAICOM)}

The Insurance Act 2003 vested the responsibility to regulate and supervise insurance businesses on NAICOM. Section 4(1) of the Act states that "subject to the provisions of the Act, no insurer shall commence business in Nigeria unless the insurer is registered by NAICOM". Also, NAICOM Act 2007 empowered it to license and supervise the operations of all classes of insurance business in Nigeria.

\subsubsection{National Pension Commission (PenCom)}

PenCom is charged, under the Pension Reform Act 2004 as amended, to regulate and supervise the operations of Pension Fund Custodian (PFC), Pension Fund Administrators (PFA) and any other operators in the pension sub-sector.

\subsubsection{Financial Services Regulation Coordinating Committee (FSRCC)}

The CBN Act 1994 and 2007 as amended provided for the creation of the FSRCC to coordinate and harmonize the activities of the various regulators and supervisors in the financial system with a view to minimizing regulatory arbitrage. The Committee is chaired by the Governor of the CBN.

\subsubsection{Economic and Financial Crimes Commission (EFCC)}

The Nigeria Financial Intelligence Unit of the EFCC is charged with the mandate of receiving, collating and analyzing currency transaction reports (CTRs) and suspicious transactions reports (STRs) from FIs with a view to checkmating money laundering and countering financing of terrorism. 


\subsection{Regulatory Regime in Nigeria}

None of the risks to which banking is prone can be avoided entirely. They can only be minimized, mitigated or optimized, in other words managed (Golin, 2001). Similarly, the very nature of banking which is based on accepting short term deposit in small irregular amounts at erratic intervals and lending out the same funds in typically larger blocks for fixed terms, makes some gap in tenor between a bank's assets (loans) and its liabilities (deposits) inevitable and the possibility of a shortfall in liquidity or a potential squeeze on profits inescapable. The quality of the regulatory regime governing banks has three elements dramatized below

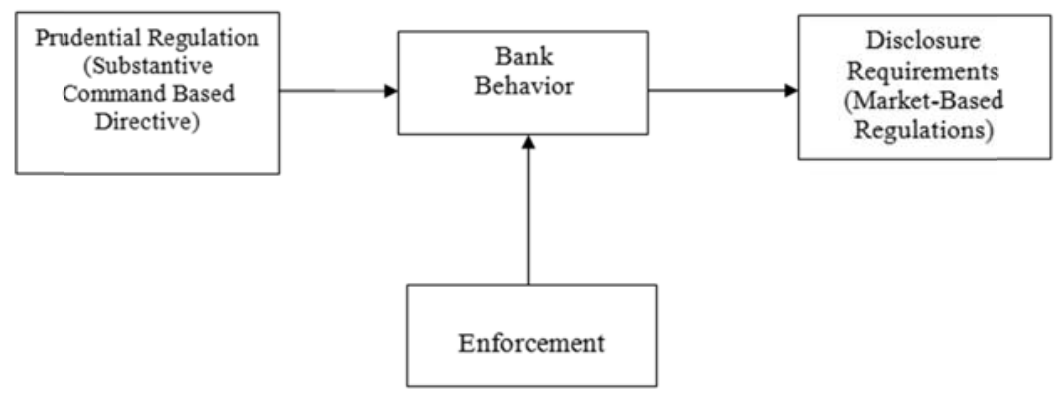

Figure 1. Three elements of regulatory regime (Source: Adapted from Jonathan Golin 2001)

One is the use of market-mechanisms; the second is the ability of government to command specific behaviors through its police power and the force of law. Thus one element of the quality of a regulatory regime can be discerned in the extent regulators compel disclosure which enables the market to respond by effectively punishing a bank that appears to be sailing too close to the wind and in danger of capsizing. A second element can be found in the degree to which regulators mandate substantive policies that require banks to maintain adequate loan loss provisions while the last element of regulatory regime is the ability and will of the regulatory authorities to enforce their directives, whether disclosure oriented or substantive in nature.

\section{Causes of Bank Failures in Nigeria}

The series of bank failures in Nigeria had been known to emanate from three basic factors of institutional, economic and political factors. But for this paper, we will exhaustively discuss the causes of bank failure under the institutional factor. These are factors that fall largely within the purview of the owners and management of the banks. However, every bank failure in Nigeria is traceable to the following institutional factors:

\subsection{Insider Loans Abuses}

The high level of insider's loans abuses is one of the significant factors responsible for the series of bank failure in Nigeria (Ugoani, 2015). Ogunleye (2010) asserts that many owners and directors of failed banks abuse or misuse their privileged positions or breach their fiduciary duties by engaging in self serving activities. These insider loans/abuses range from

i. Granting of unsecured loan facilities to owners, directors and allied companies in violation of BOFIA 1991 as amended.

ii. Approval and granting interest waivers on non-performing insider loans.

iii. The use of bank resources to services their other business interests such as allocation of foreign exchange.

According to Abiodun \& Ojo, (2012) the Defunct City Express Bank and Finbank had \#12billion and \#16billion bad loans respectively that were directors related. Consequently, some CEO/MD of some failed banks that granted loans to the height of \#125billion are currently standing trial in several courts in Nigeria. Furthermore, the granting of credit facilities in excess of \#9billion also led to the collapsed 
some banks in Nigeria in recent times. This huge credit became bad the management team hired by the Central Bank of Nigeria to resuscitate the ailing bank instead promptly wrote off the bad loan of about \#9.7 billion by way of waivers. However, the height of insider loan/abuses in some of the failed and liquidated banks is shown in the table below.

Table 5. Statistical evidences of loans granted to owner and directors

\begin{tabular}{l|l|c|c|c}
\hline S/No & Banks(in-Liquidation) & $\begin{array}{l}\text { No. of Directors } \\
\text { Involved }\end{array}$ & $\begin{array}{l}\text { Amount as at } \\
\text { Closure }\end{array}$ & $\begin{array}{l}\text { \% of Total Risk } \\
\text { Assets }\end{array}$ \\
\hline 1 & Alpha Merchant Bank Plc & 11 & $1,314,418,700.43$ & $33 \%$ \\
\hline 2 & United Commercial Bank Ltd & 5 & $741,755,808.86$ & $30 \%$ \\
\hline 3 & Financial Merchant Bank Ltd & 1 & $383,061,096.00$ & $100 \%$ \\
\hline 4 & Highland Bank of Nig. Plc & 12 & $33,197,157.58$ & $38 \%$ \\
\hline 5 & Commercial Trust Bank Ltd & 1 & $247,749,719.10$ & $38 \%$ \\
\hline 6 & ABC Merchant bank Ltd & 8 & $272,981,634.00$ & $49 \%$ \\
\hline 7 & Royal Merchant Bank Ltd & 7 & $646,940,182.23$ & $69 \%$ \\
\hline 9 & North-South Bank of Nig. Ltd & 13 & $240,668,637.62$ & $32 \%$ \\
\hline 10 & Abacus Merchant Bank Ltd & 14 & $568,888,254.11$ & $47 \%$ \\
\hline 11 & Credite Bank Nig. Ltd & 6 & $379,634,611.47$ & $76 \%$ \\
\hline 12 & Prime Merchant Bank Ltd & 1 & $539,292,310.00$ & $64 \%$ \\
\hline 13 & Amicable Bank of Nig. Ltd & 7 & $149,854,896.00$ & $56 \%$ \\
\hline 14 & Group Merchant Bank Ltd & 5 & $272,072,261.00$ & $32 \%$ \\
\hline 15 & Commerce Bank Plc & 13 & $595,836,077.20$ & $80 \%$ \\
\hline 16 & Pinnacle Commercial Bank Ltd & 4 & $1,294,851,665.64$ & $52 \%$ \\
\hline 17 & Republic Bank Ltd & 10 & $298,766,751.76$ & $20 \%$ \\
\hline
\end{tabular}

Source: NDIC Report 2011

\subsection{Weak Corporate Governance}

Corporate governance issues continue to impede banking system profitability and stability in many places. Inept management and corruption accelerate the rate of bank failure in Nigeria (Ugoani, 2015). Udunze (2013) reports that as the result of investigations regarding corporate governance breaches the CEO of Ecobank transnational agreed to forgo US $\$ 1.14 \mathrm{~m}$ bonus he was to earn for the 2012 financial year as part of efforts to rebuild public confidence in the bank against the backdrop of accusations of maladministration, fraud and technical incompetence in the bank. Inept management and corruption accelerate the rate of bank failures in Nigeria. Also Itua (2013) reports that the ex-MD/CEO of one of the failed banks was involved in the fraudulent deals involving US\$11million. The number of banks adjudged as satisfactory dropped from 63 in 2001 to 51 in 2004. The bank failure syndrome continued through the years to 2011, when six banks collapsed due largely to poor credit risk management with a potential loss of about N700bn. The following are responsible for bank failures under the weak corporate governance framework:

i. Inability/difficulty of management of failed banks to adhered to corporate governance codes and prudential standard.

ii. Contravention in keeping proper books and accounts as prescribed by laws, rules and regulations.

iii. Most failed banks in Nigeria are characterized with weak and poor internal control systems. This weak internal control is evidence in the height of frauds and forgeries in the failed banks.

iv. Some of the failed banks are occupied with, inexperienced, unqualified and incompetent personnel occupying top and key positions in the banks (Olufon, 1992).

This is because many investors see business as personal or family business and as such children and family members who are not qualified in any way are employed into key position in the bank. 


\subsection{Poor Risk Asset Management}

The spate of bank failure in Nigeria is attributed to poor credit policies in place. A situation where loans are granted without detailed and proper analysis of the loan applicant, that is banks grant loans without collateral while some loans request are granted on the basis of order from above (Okpara, 2009). Many banks in Nigeria have witnessed large asset and liability mismatch in the bank balance sheet because they relied heavily on public sector funding for liability generation and when these funds were recalled from banks, it threw them into serious problems. Of course, this action put a lot of strain on bank capital and this was clearly showed in CBN's response by regularly increasing the capital limit of every banking policy reforms.

\section{Bank Failures in Nigeria: The Role of the Prudential Regulator}

The role of the CBN as a prudential supervisor and regulator of the nation's banking sector with regards to the waves of bank failure was keenly reviewed. We discovered that the CBN should be blamed for being laxy over her routine functions as the supervisor and regulator of the banking sector. It was worrisome that the CBN was unable to unearth the sharp practice going on at various banks operating in the country not just because of lack of manpower (personnel) but those that are competent and skilled. Coupled with this challenge and together with the liberation of the banking sector in the 80s made so many banks went through the accounting period without the on-site examination by the CBN while in some cases the on-site examination by the supervisor and regulator of the nation's banking sector were conducted at interval of two to three years (Ogunleye, 2010). This of course led to the bank failures the sector experience in recent times as the problems of the banks were detected very late and this made them failed. Further those CBN personnel charge with the responsibility of examining the banking institutions in Nigeria are unprofessional and incompetent. In fact, they lack the required expertise to detect fraudulent and sharp practices of some banks in the system. This also helps to constitute issues causing bank failure in the country. The advent of information technology and the proliferation of banking sector in Nigeria have eased data manipulation by banks thereby facilitating window dressing of banks balance sheet.

Secondly, the poor and weak structure of the banking supervision department has also hindered the effectiveness of the department with respect to monitoring and enforcement of regulation (Sanusi, 2010). As such no specific individual is assigned the duty of covering the supervisory role of the on-site and offsite examination of banks. In most cases, such individual may work unilaterally since they are based on different location. Also the lack of strong co-ordination between the CBN, NDIC and SEC is another regulatory laxity and lapses. This lapse has weakened their ability to detect sharp practices adopted by the banks in investing in the capital market. These apex regulatory bodies have never for once exchange banks examination reports among themselves with the view to improve their supervisory and regulatory functions bearing in mind the importance of the banking sector and capital market to the Nigeria economy.

Thirdly, the mismatch in CBN macroeconomic policies is a major failing of the supervisor and regulator of the banking sector. Failure of the macroeconomic policies to make headway against the current economic challenges shows there is no structure put in place by the CBN to ensure that the Nigeria economy is adequately managed in tandem with the banking sector. Furthermore, banks operating in the country continued to face series of challenges on the heels of capital, foreign exchange income and asset quality. The dwindling global oil prices also added to banks woes. Presently, all macroeconomic indices have turned hostile to the welfare of citizen. Inflation rate spiked to 17.26 percent in April 2017 before it dropped to 17.24 percent in May, while unemployment rate (which measures the number of people actively looking for a job as a percentage of the labour force) rose for the seventh straight quarter to 13.9 percent in the third quarter of 2016. This is reported to be the highest in more than five years and this weak macroeconomic environment has continued to exert pressure on the banking system.

Finally, the political arrangement surrendering the appointment of the CBN Governor makes it a difficult one for any CBN Governor to function effectively and independently. Consider a situation whereby the appointment of the CBN Governor is made on a zoning basis, this arrangement is not in the best interest of the country and devoid of international best practices. This creates room for 
expertise to be sacrificed on the altar of sentiment and tribalism. Also in Nigeria, many promoters of banks are well connected to the political class with majority of these promoters contributing to the campaigns of the various members of this political class. This of course will definitely lead to regulatory forbearance.

\section{Conclusions}

The revelations from this study have confirmed the scare that the crisis ravaging the sector over these periods have not been dealt with by the regulatory authority and other stakeholders in the sector, as such one could conclude that poor implementation of the prudential guidelines to a large extent contributed to the series of bank failure witness in Nigeria over these years and failure of the CBN to carry out some of its routine functions also accounts for bank failure in Nigeria. The study recommends that first; the regulatory authorities of the banking sector should wake up to her responsibilities of supervising and regulating banks activities in Nigeria. Secondly the prudential guidelines should be implemented to its fullness. Thirdly, there should be strong coordination among the various regulatory authorities such that will encourage exchange of banks examination reports among themselves with the view to improve their supervisory and regulatory functions.

\section{References}

1. 1Adeyemi, B. (2011) Bank Failure in Nigeria: Consequences of Capital Inadequacy, Lack of Transparency and Non-Performing Loans. Banks and Bank Systems, 6(1), 99-109.

2. Abiodun, F., \& Ojo, Y. A., (2012). House Orders NDIC to Recover Loans. The Guardian Newspaper. 29(12192), $51-52$.

3. Akinyooye, R.F., (2006). The Challenges of Implementing the Basel 2 Accord in Nigerian Banks. PhD thesis Submitted to the Department of Management St Clement University.

4. Alashi. S.O., (2002). Banking Crisis: Causes, Early Warning Signals and Resolutions.

5. Balogun, O.O., (2011). A Review of the Central Bank's Role as Prudential Regulator in Nigeria: An Analysis of the Case of a Separate Supervisory Agency? An LLM Dissertation Submitted to the Institute of Advance Legal Studies, School of Advance Study University of London.

6. CBN (2002). Enhancing Financial Sector Soundness in Nigeria, Abuja. Retrieved from www.cenbank.org on 24th October, 2016.

7. Chude, N.P. \& Chude, D.I. (2014). The Relationship Between Regulatory Inconsistencies and Nigeria Banking Industry. Research Journal of Finance and Accounting, 5(13), 67-75.

8. Egbo, O.P., (2012). Universal Basis of Bank Failure. The Nigeria Cases. Developing Countries Studies, 2(1), 119131.

9. Itua, F., (2013). Saraki: EFCC Quizzes Mbonu, ex-MD, SGBN. Daily Sun, Vol. 10, pp 55.

10.Jonathan, G. (2001). The Bank Credit Analysis Handbook. A Guide for Analysts, Banker and Investors. John Wiley \& Sons (Asia) Pte Ltd.

11.Nigeria Deposit Insurance Corporation Annual Report (2009) http://ndic.org.ng/files/ndic_2009_annual_report. pdf.

12.Nzotta. S.M., (2004). Money, Banking \& Finance, Theory and Practice. Hudson-Jude Nigeria Publishers Owerri Imo State Nigeria.

13.Obamuyi, T.M. (2011). Incessant Bank Distress and the Policies of Central Bank of Nigeria. International Journal of Finance and Accounting, 1(1), 1-10

14. Ogunleye, G., (2010). The Causes of Bank Failure and Persistent distress in the banking Industry: Perspectives on the Nigerian Financial Safety-Net, Chapter 4. http://ndic.org.ng/files/Perspectives\%20\%20On\%20 the\%20Nigerian\%20Financial\%20Safety-net\%20NDIC\%202.pdf.

15.Ohwofasa, B.O., \& Mayuku, J.G. (2012) Determinants of Bank Distress and Effect on Nigerian Economy, 19862010: An Empirical Analysis. European Journal of Humanities and Social Sciences, 17(1), 865-875.

16.Okpara, G., (2009). A Synthesis of the Critical Factors Affecting Performance of the Nigerian Banking System, Journal of Economics, Finance and Administrative Sciences, 17(1), 25-48. 
17. Olufon G., (1992). Problem of Boardroom Imbroglio Afflicting the banking industry in Nigeria: The leadership role of Board Chairman in Bank Management", Published Chartered Institute of Bankers Nigeria.

18.Sanusi, L., (2010). The Nigerian Banking Industry: What went wrong and the way forward. Convocation Lecture, Bayero University Kano. http://www.cenbank.org/out/speeches/2010/the\%20nigerian\%20 banking\%20industry\%20what\%20went\%20wrong\%20and\%20the\%20way\%20forward_final_260210.pdf.

19.Sanusi, L., (2009). Press Address by the Governor of Central Bank of Nigeria on Developments in the Banking System in Nigeria. http://www.cenbank.org/out/speeches/2009/govadd-14-8-09.pdf.

20.Sanusi, L., (2010).Global Financial Meltdown and the Reforms in the Nigerian Banking Sector. Convocation Lecture Abubakar Tafawa Balewa University. http://www.cenbank.org/out/speeches/2010/ gov_atbu\%20convocation\%20lecture.pdf.

21.Udunze, B., (2013). Ecobank's CEO foregoes $\$ 1.14 \mathrm{~m}$ Bonus: Daily Sun, Vol. 10, pp. 55.

22.Uwatt, U.B. (2015) Regulatory Framework and Regulatory/Supervisory Institution http://finance.onlinenigeria. com. 